\title{
OPINION STUDY AMONG TEACHERS AND STUDENTS ON THE PRACTICE OF CORPORAL PUNISHMENT IN SCHOOLS
}

\author{
Binu Sahayam D ${ }^{*}{ }^{\natural}$ \\ ${ }^{1}$ Assistant Professor, School of Advanced Sciences, Vellore Institute of Technology, Chennai, \\ Tamilnadu, India
}

\section{DOI: https://doi.org/10.29121/granthaalayah.v8.i5.2020.51}

Article Type: Research Article

Article Citation: Binu Sahayam D. (2020). OPINION STUDY AMONG TEACHERS AND STUDENTS ON THE PRACTICE OF CORPORAL PUNISHMENT IN SCHOOLS. International Journal of Research GRANTHAALAYAH, 8(5), 32-37. https://doi.org/10.29121/granthaa layah.v8.i5.2020.51

Received Date: 05 May 2020

Accepted Date: 25 May 2020

Keywords:

Corporal Punishment

Types of Corporal Punishment

School

Opinion

\begin{abstract}
Corporal punishment is wide spread in schools in spite of Government orders and protests from NGOs against this practice. Corporal punishment, besides inducing physical injuries, causes deep emotional wounds resulting in students attempting suicide. In this paper, the author highlights some of the issues associated with corporal punishment based on the study conducted among school teachers and school students in North Chennai. The research design used in the study is descriptive in nature. In this study, schools were randomly selected for the study. The main objective of the study is to elicit the opinion of teachers and students on the practice of corporal punishment in schools. The findings indicate that corporal punishment is highly prevalent in schools irrespective of the categories of schools. The study concludes with the implication of social work practices in school to handle issues of corporal punishments.
\end{abstract}

\section{INTRODUCTION}

According to census 2011, "there are 472 million children in India are under the age of 18 years i.e., Children constitute around $39 \%$ of the total population. The facts also underlines that " 1 in 4 children are in the age of getting access to school education but they are out of school" (Census 2011)"1. This data illuminates that only fewer population are going to school whereas majority are school drop-outs. The Article 21 of Indian constitution represents that every child has the right to free and compulsory education yet 99 million children in total have dropped out of school (Census 2011) ${ }^{2}$. Some of the reasons for school drop-outs are children face socio-economic issues, family disputes, undergo issues in school with peer groups, may not like the behavior of teachers, treating behavior of management and school based on social status, too much of work pressure and assignments, disciplinary actions causing physical, psychological and emotional stress, management due to which children becomes school dropouts. This is an arising and an alarming problem which need to be addressed because" $65 \%$ of school going

${ }^{1}$ Child rights and you 2020.Statistics Of Children In India. Retrieved from URL :< https://www.cry.org/statistics-on-children> Accessed on 25 April 2020 at 20.10pm\}

${ }^{2}$ Child rights and you 2020.Statistics Of Children In India. Retrieved from URL :< https://www.cry.org/statistics-on-children> Accessed on 25 April 2020 at $20.30 \mathrm{pm}\}$

(C) 2020 The Author(s). This is an open access article distributed under the terms of the Creative Commons Attribution License, which permits unrestricted use, distribution, and reproduction in any medium, provided the original author and source are credited. 
children reported facing corporal punishment i.e. two out of three children were victims of corporal punishment and $62 \%$ of the corporal punishment was in Government and Municipal school." (Kacker, 2007). School bullying, Corporal punishment, relationship barrier are some of the problems faced by children in schools. This study explores how corporal punishment affects the life of a child and the reasons behind for school dropouts and the implications of social work practice.

\subsection{OBJECTIVE}

The objectives of the study are as follows:

1) To study the demographic details of the respondents

2) To study the opinion of teachers and students on the practice of corporal punishment in schools.

3) To understand the prevalence of corporal punishment in schools

4) To study the cause and impact of corporal punishment in schools

\subsection{WHAT IS CORPORAL PUNISHMENT?}

In this study corporal punishment includes physical, verbal and emotional abuse of a student by a teacher with a view to enforce discipline. Corporal punishment is a regular affair in schools. Children not only carry overload of text books and note books on their tender backs, but also get punished for reasons like not tying the shoe lace properly, not following the school dress code, not combing the hair properly, and not wearing identity badges and so on. A study by Gebrezgabiher and Hailu (2017, cited in Save the Children Norway, 2004) and Ame et al., 2011) has highlighted that academic performances in one of the major reasons. In another study by Gebrezgabiher and Hailu (2017, cited in Agbenyega, 2006) study reports that around 94-98\% teachers used corporal punishment for students who are very weak in their academic performance. Teachers believe sparing the rod to save the children is a kind of disciplinary action. A report of the Ministry of Women and Child Development (2006) clearly indicates the kinds of punishments in schools. The list has been reproduced from the Government report.

There are three kinds of punishments in schools and some are mentioned in researcher studies of Kacker(2007:43) and Gebrezgabiher and Hailu (2017)

\subsection{PHYSICAL PUNISHMENT}

1) Making the children stand as a wall chair

2) Keeping the school bags on their heads

3) Making them stand for the whole day in the sun

4) Make the children kneel down and do the work

5) Making them stand on the bench

6) Making them raise hands and stand

7) Hold a pencil in their mouth and stand

8) Holding their ears with hands passed under the legs

9) Tying of the children's hands

10) Making them to do sit-ups

11) Caning and pinching

12) Twisting the ears

13) Hit the students with any kind of materials like chalk piece, dusters, note books etc

\subsection{EMOTIONAL PUNISHMENT}

1) Slapping by the opposite sex

2) Scolding the students using bad words

3) Humiliating the students in front of their classmates

International Journal of Research -GRANTHAALAYAH 
4) Labeling the child according to their behavior and sent him/her around the school

5) Make them stand on the bench and ask the students to complete the work

6) Suspending the students for couple of days

7) Pinning paper on their back and labeling them 'I am a fool, I am a donkey, I am unfit, etc

8) Taking the students to other classes and humiliating the students

9) Removing the shirts of the boys

\subsection{NEGATIVE REINFORCEMENT}

1) Detention during the break and lunch

2) Locking them in a dark room

3) Call for parents or asking the students to bring explanatory letters from their parents

4) Sending them home

5) Not allowing the students to enter into the school campus

6) Making the student sit on the floor in classrooms

7) Making the student to clean school premises

8) Sending the children to principals

9) Making them to teach in the class

10) Making them to stand till the teacher comes

11) Giving oral warning and letters in the diary or calendar

12) Threatening to give TC for the child

13) Asking them to miss games and other activities

14) Deducting marks

15) Treating the three late comings equal to one absent

16) Giving excessive imposition

17) Making the children to pay fines

18) Not allowing them into the class

19) Sitting on the floor for one period, day, week and month

20) Placing black marks on their disciplinary charts

\subsection{LAW AND CORPORAL PUNISHMENT}

The Indian Penal code of Section 88 safeguards "Acts not intended to cause death, done by consent in good faith for person's benefit" and Section 89 protects "Act done in good faith for benefit of child or insane person, by or by consent of guardian (The times of India, 2019), both these section 88 and section 89 imprints that punishments are given for the benefit of child's growth and development and forbid from bad behavior. In another study by Rajan and Kannappan (2018:1320) highlighted on the National Charter for Children 2003, National Plan of Action for Children (2006), the Right to Education Act (2009), Article 21A 'Free and Compulsory Education for children between the ages of 6 and 14, insists teachers to ban corporal punishment in schools. Articles 19 of the United Nations Convention on the Rights of the Child emphasize on the Protection from all forms of violence.

\subsection{STATEMENT OF THE PROBLEM}

Corporal punishment in schools could defeat the whole purpose of imparting education in educational institutions. It affects the psychosocial development of the students. Corporal punishment is of various forms, it can be verbal or non-verbal. Any form of punishment will affect the students physically, psychologically and emotionally. If this continues it will affect the growth and development of a child. The study is to elicit information on corporal punishment in schools and its affects an individual development. At the same time teachers also face psychological turbulences when handling a mischievous student in the class and this is the major reasons for implementing corporal punishments. 


\subsection{IMPORTANCE OF THE STUDY}

In India, under the Prevention of Cruelty Animals Act, $1960^{3}$ animals are protected against any form of cruelty but not for a child in an educational institution. There is a myth among educational institutions and parents that corporal punishment can be administered in schools and it is the best form of discipline. Teachers should keep in mind that teaching and handling students should go hand in hand. Students are sensitive and vulnerable section in the society and teachers should make them aware of their behavior and performance in schools. Parents also should cognize that education is not only grade oriented. Education is a culmination of learning, updating knowledge, developing cognitive and analytical skills in shaping one's personality development. Parents and teachers should forget of corporal punishment in imparting education or shaping their children behavior. Instead of corporal punishment alternatives correcting methods can be adopted such as making the students to take class, assigning class responsibilities, counseling if required and so on. The study is important in this context.

\section{MATERIALS AND METHODS}

On a random basis six schools were selected in North Chennai. These comprised of two corporation higher secondary schools, two private matriculation schools and two schools classified under religious minority institutions. Thirty-three teachers and thirty three students totally amounting to sixty six respondents were randomly selected for the study. Only girl students studying in class $9^{\text {th }}$ and $10^{\text {th }}$ were included for the study. A detailed interview schedule, in keeping with the objective of the study was developed by the researcher. Data collection was done through personal interviews with each respondent. The study was Descriptive in nature. Some of the significant findings of the study have been listed here.

\section{RESULTS AND DISCUSSIONS}

Main Findings (give 52 percent, more than half of the respondents)

1) The mean age of the teachers was 36 years.

2) Fifty one percent of the respondents were women teachers.

3) Sixty one percent of the respondents were married.

4) Fifty five percent of the teachers were post graduate with B.Ed qualification.

5) Seventy nine percent of the respondents had been employed as teachers for 5 to 10 years.

6) A vast majority $82 \%$ of the teachers expressed that corporal punishment is required to discipline the child.

7) There was no variation with regard to the gender of the teachers in approving corporal punishment.

8) Sixty seven percent of the teachers stated that the parents of the school children had accepted corporal punishment as part of school life.

9) Not doing the home work and naughty behavior in the class were the main reasons that attracted corporal punishment.

10) Corporal punishment was followed in all categories of schools.

11) The students were in the age group of 13-16 years.

12) Seventy six percent of the students stated that they were subjected to corporal punishment atleast once a week.

13) Twenty one percent of the students suffered from severe headache after physical punishment.

14) Fifty two percent of the students expressed that they had physical injuries due to corporal punishment.

15) Seventy percent of the students expressed intense anxiety and fear due to corporal punishment.

16) Eighty five percent of the students were against corporal punishment as it causes severe psychological disturbances.

17) Sixty nine percent of the students stated that their parents encouraged corporal punishment.

\footnotetext{
${ }^{3}$ See at: $<$ http://www.awbi.org/awbi-pdf/APL.pdf $>$ [Accessed on 29 April 2020 at 19.08pm]
} 
18) Fifty one percent of the students had disturbed interactions with those teachers who had subjected them to corporal punishment.

\section{CONCLUSIONS AND RECOMMENDATIONS}

\subsection{IMPLICATIONS FOR SOCIAL WORK PRACTICE}

The findings indicate that corporal punishment is highly prevalent in schools irrespective of the categories of schools. Therefore, there is an urgent need to appoint school social workers who can professionally intervene with the teachers, students and parents.

Every school should appoint one School social worker and their role is very significant. They can play the role of a catalyst when a child is found to be with any kind of stress or learning disability or relationship issues or found to be hyperactive or lack of discipline etc. It is difficult to read a child's mind and behavior when found to be guilty. Nowadays children are becoming very shrewd in sorting out as well as dealing their issues by themselves without any ones support. In such case, school social worker can intervene and help the child to overcome any complications through the process of counseling. Counseling is one of the best initiatives and can be rendered for a child's betterment. Thus, the process of positive intervention by social school worker can yield results in the wellbeing of child.

The negative consequence of corporal punishment or any action against a child can be highlighted by school social workers to the management/teachers and parents. School social worker should be given opportunity to participate in meetings and share information on children's behavior, learning disability for poor performance or any depression problems and focus on student-teacher relationship and strategies to make the environment friendly in developing the child to become more self-reliant.

Besides conducting awareness campaigns the school social workers can distribute information through printed leaflets on 'Child Friendly School Practices' as advocated by UNICEF. Social workers need to take up more research studies to assess the effects of corporal punishment on school students and adopting healthy measures of enforcing discipline in schools.

India being a signatory to the UN conventions of the rights of the child, is under obligation to ensure that children are not subjected to corporal punishment in schools. The Suicide rate of adolescent students in the country has been increasing every year. Corporal punishment can induce more such suicides. The message to schools is Spare the rod and save the child.

\section{SOURCES OF FUNDING}

None.

\section{CONFLICT OF INTEREST}

None.

\section{ACKNOWLEDGMENT}

None.

\section{REFERENCES}

[1] Bose. 2003. The state of children in India promises to keep. Manohar publication and Distributors: New Delhi

[2] Child Protection - A handbook for teachers, Ministry of Women and Child Development, Government of India, New Delhi 2006. 
[3] Corporal punishment against children and the law. The times of India. 2019. Retrieved from URL :<https://timesofindia.indiatimes.com/blogs/legally-speaking/corporal-punishment-against-children-andthe-law/> [Accessed on 25 April 2020 at 20.46pm]

[4] Gershoff. T Elizabeth and Font. A Sarah. 2016. Corporal Punishment in U.S. Public Schools: Prevalence, Disparities in Use, and Status in State and Federal Policy

[5] Gebrezgabiher1, G.Gebru and Hailu, K. Gebreslassie. (2017) Corporal Punishment of Children's in School: A Critical Literature Review. International Journal of Advancements in Research \& Technology, 6(5), ISSN 2278-7763. Retrieved from URL :<http://www.ijoart.org/docs/Corporal-Punishment-of-Childrens-inSchool-A-Critical-Literature-Review.pdf $>$ [Accessed on 29 April 2020 at 16.08pm]

[6] Kacker, Loveleen et al. (2007). Study on Child Abuse INDIA 2007. Prepared by Ministry of Women and Child Development, Government of India, New Delhi. Retrieved from URL :< http://www.indianet.nl/pdf/childabuseIndia.pdf>. [Accessed on 28 April 2020 at 14.46pm]

[7] Rajan S. Saravana and Kannappan. M. (2018). A Study on Corporal Punishment and Child Rights with Special Reference to India. International Journal of Pure and Applied Mathematics. 119(17), 1315-1324. ISSN: 1314-3395. Retrieved from URL :< http://www.acadpubl.eu/hub/>. [Accessed on 26 April 2020 at 20.08pm]

[8] R. Kalaivani, "A Study on Corporal Punishment in Schools at Sivakasi” International Journal of Research Granthaalayah, 4(2): 31-3. Retrieved from URL :<http://granthaalayah.com/Articles/Vol4Iss2/03_IJRG16_A02_48.pdf> [Accessed on 29 April 2020 at $13.08 \mathrm{pm}]$

[9] Kumar.K and Rani, Punam. (1996). Offences against children. Regency Publications

[10] Muttalib.M.A. (1990). Child developments. Sterling publications Private Limited. 